\title{
Does climatic warming explain why an introduced barnacle finally takes over after a lag of more than 50 years?
}

\author{
Sophia Witte $\cdot$ Christian Buschbaum • \\ Justus E. E. van Beusekom · Karsten Reise
}

Received: 3 June 2009/Accepted: 29 March 2010/Published online: 21 April 2010

(C) Springer Science+Business Media B.V. 2010

\begin{abstract}
Invading alien species may have to await appropriate conditions before developing from a rare addition to the recipient community to a dominance over native species. Such a retarded invasion seems to have happened with the antipodean cirripede crustacean Austrominius modestus Darwin, formerly known as Elminius modestus, at its northern range in Europe due to climatic change. This barnacle was introduced to southern Britain almost seven decades ago, and from there spread north and south. At the island of Sylt in the North Sea, the first A. modestus were observed already in 1955 but this alien remained rare until recently, when in summer of 2007 it had overtaken the native barnacles Semibalanus balanoides and Balanus crenatus in abundance. At the sedimentary shores of Sylt, mollusc shells provide the main substrate for barnacles and highest abundances were attained on mixed oyster and mussel beds just above low tide level. A. modestus ranged from the upper intertidal down to the subtidal fringe. Its realized spatial niche was wider than that of the two natives. We suggest that at its current northern range in Europe a long series of mild winters
\end{abstract}

C. Buschbaum · J. E. E. van Beusekom · K. Reise ( $₫)$ Alfred Wegener Institute for Polar and Marine Research, Wadden Sea Station Sylt, 25992 List, Germany

e-mail: karsten.reise@awi.de

S. Witte

BioConsult SH, Brinckmannstr. 31, 25813 Husum, Germany and several warm summers in a row has led to an exponential population growth in A. modestus.

Keywords Alien species - Austrominius modestus . Invasion $\cdot$ Climate change $\cdot$ North Sea

\section{Introduction}

Translocation of species across natural barriers by human carriers has become a process of increasing global importance in aquatic coastal ecosystems (Carlton 1985; Grosholz 2002). The success of alien invaders is primarily a function of (1) propagule pressure such as at ports or open aquaculture facilities for coastal aquatic species (2) superiority by means of attributes evolved in another evolutionary context (3) release from co-evolved enemies (4) synergisms with other alien invaders (5) availability of resources in recipient ecosystems, and (6) environmental change which may stress natives but benefits pre-adapted aliens (i.e., Alpert 2006; Barney and Whitlow 2008; Sax et al. 2007; Westphal et al. 2008). The last mentioned process may turn an alien species previously considered to be a harmless addition to the recipient biota into an invader of high competitive ability. The recent global warming may entail such shifts in dominance when aliens originate from a warmer environment than their recipient regions 
(Dukes and Mooney 1999; Occhipinti-Ambrogi 2007; Reise et al. 2008). Thus, in cold temperate waters the biota may already comprise several aliens suspected to be 'sleepers'. Most sources of introduced species, ports and aquaculture facilities, are located in warmer regions. Introduced long ago, sleepers may be awakened by recent climatic warming, and then potentially may run for dominance. Such time lags can be found in all phases of the invasion process of alien species (Crooks and Soulé 1999; Crooks 2005). An end of a time lag is often caused by changes in abiotic conditions of the receiving environment but may also be triggered by other factors like changes in the invader (e.g. genetics) or relaxation of biotic pressures. However, the awakening of ecological sleepers after decades due to global warming is in contrast with the common pattern of introduced aliens which after a short initial phase enter a boom and bust development, followed by a long adjustment phase with more moderate densities (Reise et al. 2006).

The barnacle Austrominius modestus Darwin (1854), formerly known as Elminius modestus (O'Riordan et al. 2009; Buckeridge and Newman 2010), originating from southern Australia and New Zealand, arrived in British waters some time prior to 1943, presumably by navy vessels or flying boats (Bishop 1947; Crisp 1958). Since then it has extended its range into the North Sea and the Atlantic shores, probably by a combination of larval drift and hitchhiking on boats or as larvae in ballast water (Kühl 1954; Crisp 1958; Barnes and Barnes 1968). The species is also known from the western Mediterranean Sea since 1990 (Galil 2009). In 1955 the first five individuals of $A$. modestus were recorded at the shore of the island of Sylt in the North Sea (Kühl 1963), which is the site of this study. In subsequent years, A. modestus has been found regularly in low numbers, became relatively common from 1993 to 1995, then was almost absent after the severe winter 1995/96, and since then gradually increased but remained rare relative to the two native barnacles, the intertidal Semibalanus balanoides (L.) and the subtidal Balanus crenatus (Bruguière), which are overlapping around low tide level (Luther 1977, 1987; pers. obs.). Other Balanomorpha occasionally encountered around Sylt are Balanus balanus (L.) on a subtidal boulder groin; this species also occurs together with B. perforatus and B. improvisus (Darwin) on drift material washed ashore; occasionally the latter has been found attached to mussels, and Verruca stroemia (Müller) to Pacific oysters imported from Ireland (Büttger et al. 2008; Reise 1998, Reise unpubl. data).

Recent studies have shown that intertidal barnacles respond in range and abundance to current climatic warming (i.e., Mieszkowska et al. 2006; Southward et al. 2005; Wethey and Woodin 2008), and it has been suggested that increased abundances of $A$. modestus in Ireland (Lawson et al. 2004) and on the rocky island of Helgoland not far from Sylt (Franke and Gutow 2004; Reichert and Buchholz 2006) may have been facilitated by warming. A. modestus is a small, short-living, highly fecund barnacle with a physiological optimum above $20^{\circ} \mathrm{C}$ (Harms 1999) and suffers high mortality during cold winters (Crisp 1964; pers. obs.). At Sylt, the last severe winter with strong effects on the littoral fauna occurred in 1995/ 96 (Armonies et al. 2001) and since then temperatures have been increasing (MacKenzie and Schiedek 2007; Martens et al. 2008). We therefore conducted an assessment of the distribution and abundance of barnacles around Sylt. Except for coastal defence structures, shores are composed of sediments. Biogenic substrates such as mollusc shells constitute the main substrate for barnacles. We hypothesize that $A$. modestus has improved its position relative to the natives $S$. balanoides and $B$. crenatus, which used to dominate the higher and lower shore, respectively.

\section{Materials and methods}

Study area and experimental sites

Surveys and experiments were carried out in List tidal basin $\left(54^{\circ} 50^{\prime}-55^{\circ} 10^{\prime} \mathrm{N}, 08^{\circ} 20^{\prime}-08^{\circ} 40^{\prime} \mathrm{E}\right)$ in the northern Wadden Sea (eastern North Sea) (Fig. 1). The basin is enclosed by the islands of Sylt and Rømø to the west, the mainland to the east and causeways to the islands in the north and south. A narrow but deep tidal inlet between the two barrier islands connects the basin with the North Sea. The basin comprises $407 \mathrm{~km}^{2}$ of which one-third is above mean low tide level. This zone consists largely of sand flats $(72 \%)$, muddy sand $(25 \%)$ and mud flats $(3 \%)$. Tides are semidiurnal with a mean range of $2 \mathrm{~m}$. Salinity usually remains close to 30 psu (van Beusekom et al. 2008). In the 20th century, mean air 


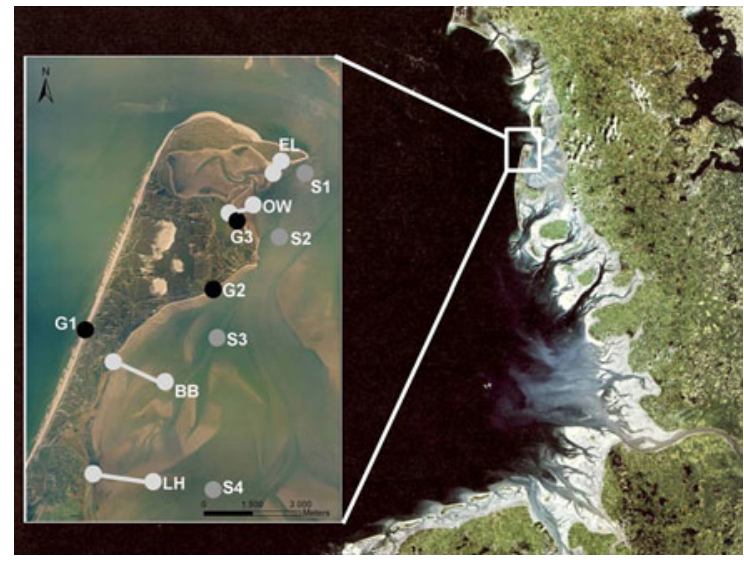

Fig. 1 Eastern North Sea with the coastal Wadden Sea and northern part of the island of Sylt (inset) with locations of transects (EL Ellenbogen, OW Oddewatt, BB Blidselbucht, LH Leghörn), dredge holes at subtidal sites (S1-4), and groins (G1-3). The bay at the northern tip of Sylt is called Königshafen. Satellite image from Eurimage, Common Wadden Sea Secretariat and Brockmann Consult

and water temperatures were $8.4^{\circ}$ and $9.0^{\circ} \mathrm{C}$ (summer $13.7^{\circ} \mathrm{C}$ and winter $5.3^{\circ} \mathrm{C}$ ), respectively. For further information about the area see Gätje and Reise (1998).

\section{Barnacle occurrence}

Six sites were sampled on the sheltered eastern side and one site at the exposed western side of the island Sylt (Fig. 1). At the sheltered site, four transects from high tide line $(+0.9 \mathrm{~m}$ above mean water level) to low tide line $(-0.9 \mathrm{~m}$ below mean water level) were surveyed to assess barnacle distribution and abundance. Adjacent to each transect, we investigated barnacle occurrence at a subtidal site (2-6 m below mean low tide level; S1-S4 in Fig. 1). In addition to the transects, we quantified barnacle density at two sheltered groins (G1 and G2 in Fig. 1) at the eastern side and at one exposed groin (G3 in Fig. 1) at the western side of Sylt.

Each transect crossed sediments with very little potential substrate as well as a mixed bed of native blue mussels Mytilus edulis L. and introduced Pacific oysters Crassostrea gigas (Thunberg) with plenty of substrate for barnacles. In the area, Pacific oysters were regularly introduced for aquaculture purposes since the mid of the 1980s, and subsequently a spread by oyster larvae to native mussel beds was observed (Reise 1998). Since 2005, most mussel beds have turned to oyster dominated reefs due to comparatively high water temperatures in summer enabling high recruitment success of $C$. gigas (Diederich et al. 2005; Kochmann et al. 2008).

Depending on barnacle densities, differently sized quadrates of $0.25 \times 0.25 \mathrm{~m}$ (smallest size) to $10 \times 10 \mathrm{~m}$ (largest size) were used for sampling, placed randomly at stations along each transect. At each transect station 3-7 replicate samples were surveyed. Within each quadrat barnacles were separated by species and counted. Of the three barnacle species encountered in this survey ( $S$. balanoides, $B$. crenatus and A. modestus), only those with a basal diameter $>2 \mathrm{~mm}$ were considered.

Stations along transects were subjectively chosen to include all tidal zones and habitat types. The three groins for coastal defence which were surveyed (Fig. 1), were made out of wooden pilings set up in double rows. Due to high barnacle density, a small frame of $2.5 \times 2.5 \mathrm{~cm}$ was used for counting, with 36 replicates at each of the three groins. All surveys were carried out in May and September 2007, respectively.

Long-term data on abundance of A. modestus attached to mussel and oyster beds in the List tidal basin were available from the literature (Albrecht and Reise 1994; Görlitz 2005), unpublished surveys of the authors, and from a blue mussel bed monitoring program conducted annually since 1998 in the northern Wadden Sea (Nehls and Büttger 2006).

\section{Barnacle recruitment}

To reveal the pattern of recruitment across the tidal gradient, cleaned oysters (maximal shell lengths 120$150 \mathrm{~mm}$ ) were offered to barnacle cypris larvae in Königshafen, a small embayment within List tidal basin (Fig. 1). Cylindrical cages (13 cm high, $25 \mathrm{~cm}$ in diameter) were made out of $1-\mathrm{cm}^{2}$ plastic meshes and were stabilized with a plastic ring above and below. In July 2007 a total of 20 cages with 3 oysters each were exposed at four tidal levels: upper $(0.3 \mathrm{~m}$ above mean water level), mean $( \pm 0.0 \mathrm{~m}$ mean water level which is equivalent to chart datum) and lower intertidal (0.6-0.8 m below mean water) and sub tidal fringe ( $1.0 \mathrm{~m}$ below mean water level). At each tidal height five cages were set up in a row with distances 
of $1 \mathrm{~m}$ between them. Each cage was anchored by 3 iron rods and pushed $5 \mathrm{~cm}$ deep in the sediment to prevent predators intruding from underneath. At regular intervals, cages were checked for entangled drift algae that were removed when necessary. Three months later in October 2007 the number of barnacles that had settled on the oysters was counted.

To investigate differences in recruitment of A. modestus between blue mussels and Pacific oysters as substrate, similar cages were set up at low tide level from July to September 2007 with cleaned M. edulis and $C$. gigas (lengths 75-90 mm). Six cages enclosed 3 oysters and 6 others had 3 mussels each. Cages were arranged in pairs within a $10 \times 10 \mathrm{~m}$ plot.

To examine whether A. modestus shows different recruitment patterns in habitats dominated by mussels (M. edulis) or oysters (C. gigas) an additional field experiment was performed. We measured the recruitment success of $A$. modestus when surrounded by mussels, Pacific oysters, both together or none of these. The experimental habitats were set up between May and June 2006. We arranged rings with oysters and mussels in circles of 2 and $4 \mathrm{~m}$ inner and outer diameter, respectively (see Kochmann et al. 2008). Rings were aligned parallel and close to low tide line in a randomized block-design, comprising 5 blocks over a distance of $110 \mathrm{~m}$ (Fig. 2). Each block consisted of 4 treatments: rings out of oysters (C), mussels (M), oysters and mussels (CM) and sediment without bivalves (S). Rings enclosed $3 \mathrm{~m}^{2}$ of bare sediment in the centre and were surrounded by a $1 \mathrm{~m}$ wide belt $\left(10 \mathrm{~m}^{2}\right)$ of the densely packed suspension feeders. At the beginning of the experiment in May 2007 one horizontal PVC-panel $(15 \times 15 \mathrm{~cm}$, and $10 \mathrm{~cm}$ above the bottom) was placed into the centre of each ring and served as a settlement substrate for A. modestus. In August, when A. modestus started to settle, panels were photographed to count the number of attached barnacles on each panel.

\section{Statistical analysis}

Abundances are given as arithmethic means with standard deviation (SD). For statistical treatment, analysis of variance (ANOVA) was used. Significant differences were analysed using Tukey's honest significant difference (HSD). Homoscedasticity of variances of dependent variables were tested by using Levene's Test. Individual tests on homogeinity of
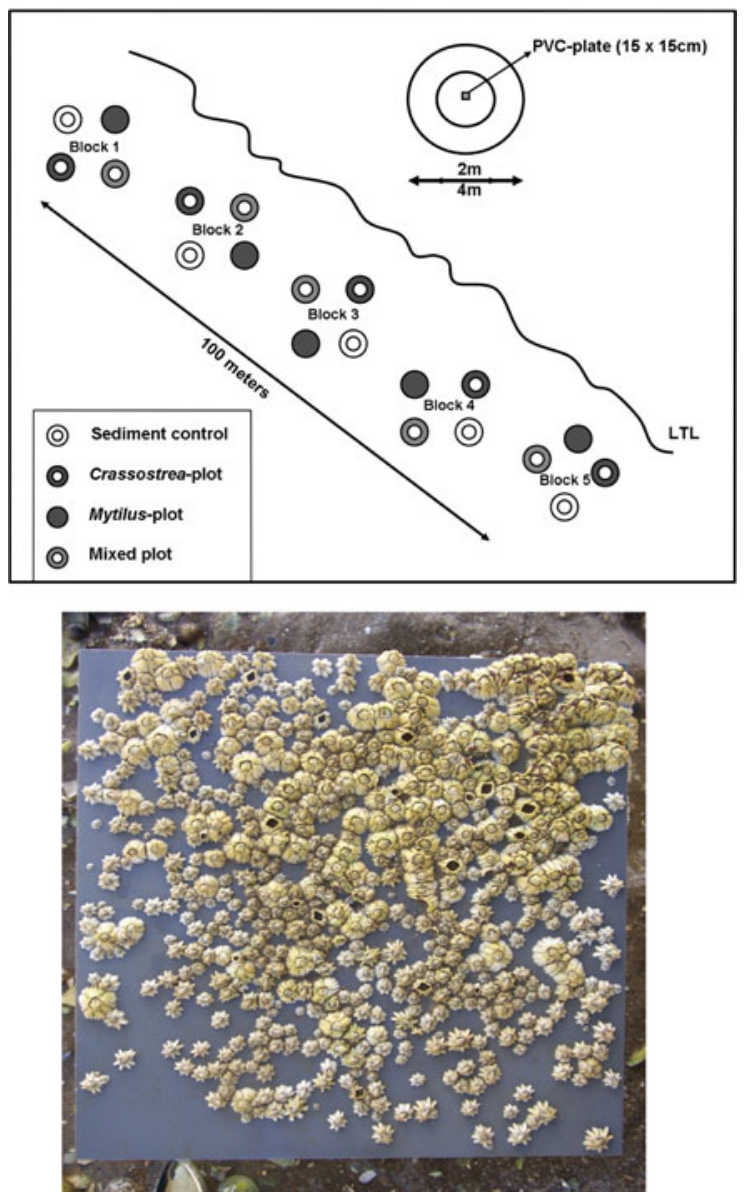

Fig. 2 Experimental set-up (above) to test recruitment behaviour of Austrominius modestus when surrounded by different habitats. The experiment was positioned just above mean low water tide line as randomized block design. Inset shows design of individual treatment and the location of PVC-plate in the centre. The PVC-plate $(15 \times 15 \mathrm{~cm})$ exposed since March shows in August 2007 a patch (upper right) of large Semibalanus balanoides and many smaller, star-shaped Austrominius modestus which settled later in summer

variances are not presented as these have little bearing on our overall conclusion on the dominance of A. modestus in the tidal zone. Heterogeneity of variances was reduced by log-transformation. For some analyses, however, transformation did not remove heterogeneity. In these cases untransformed data were used (Underwood 1997). Interpretations of analyses for which variances were heterogeneous were made cautiously, noting the robustness of analyses where sufficient samples are used. Effects were considered to be statistically significant, if $P$ was $<0.05$. 


\section{Results}

Barnacle occurrence and distribution

In the course of summer 2007, Austrominius modestus attained numerical dominance over Semibalanus balanoides and Balanus crenatus. Almost all barnacles were found attached to mollusc shells, that were either scattered as empty shells on the sediment flats or as living epibenthic mussels (Mytilus edulis), Pacific oysters (Crassostrea gigas) and periwinkles (Littorina littorea L.). Highest abundances were generally attained where mussels and oysters formed beds or reefs (Fig. 3). A. modestus and S. balanoides were primarily encountered in the intertidal zone, while $B$. crenatus was only abundant under permanently submerged conditions, occasionally together with A. modestus. Along transects in early summer, average abundance of the two intertidal barnacle species was rather similar while in late summer A. modestus by far outnumbered $S$. balanoides (Table 1). This was caused by an increase in A. modestus and a decline in the others. With respect to the coefficient of variance $(\mathrm{CV})$, the ranking was the same in early and late summer: A. modestus < $B$. crenatus $<S$. balanoides. The lowest $\mathrm{CV}$ in A. modestus indicates a more even distribution along and between transects than in the other two species.

On wooden groins, only A. modestus and S. balanoides were encountered (Fig. 4). In early summer 2007 S. balanoides was still dominant, while in September 2007 A. modestus had increased to a 5-fold higher abundance than $S$. balanoides which in turn had decreased to one-third of its former abundance. Dredged shell material at depths between 6 and $12 \mathrm{~m}$ only allowed for relative abundances. Here B. crenatus dominated entirely in September 2007. A. modestus occurred at two out of four stations (S3 and S4; see Fig. 1) with 17 out of 1,000 individuals on average. $S$. balanoides was absent.

We compiled quantitative data on the occurrence of $A$. modestus on mussel beds in the List tidal basin from separate surveys since 1990 (Fig. 5). Before 1996, A. modestus generally occurred in very low numbers and was not included in most qualitative studies (pers. obs.) and only one quantitative study is available. After 1996, A. modestus density on mussel beds increased exponentially from about 70 ind. $\mathrm{m}^{-2}$ in 1997 to about 70,000 ind. $\mathrm{m}^{-2}$ in 2007.
Barnacle recruitment

Settlement of A. modestus on cleaned and caged oysters exposed from July to October 2007 was rather variable and significantly different between tidal zones (ANOVA, $P<0.007$ ). Means (SD) per oyster in the upper, mid and lower intertidal were 14.2 (15.8), 22.9 (32.8) and 9.9 (8.7), respectively. At the shallow subtidal site settlement was significantly lower with only $1.0(0.9)$ per oyster (Tukey's HSD, $P<0.004)$, reflecting the low share of $A$. modestus on dredged material. No significant difference was found between mussels and oysters as substrate for settling A. modestus, with 2.2 (1.5) and 1.4 (1.0) individuals $\mathrm{cm}^{-2}$, respectively.

Experiments with PVC-panels surrounded by rings of oysters, mussels, both and none of these revealed no significant differences of settling cypris larvae of A. modestus in August 2007 (Fig. 6). Settling density of $S$. balanoides was similar to that of A. modestus, and also lacking a significant preference (Fig. 6).

\section{Discussion}

Recent climate change is affecting species distributions, abundances and phenologies across ecological systems (Walther et al. 2002; Parmesan and Yohe 2003). This is apparent in various biota of the North Sea (i.e., Beare et al. 2004; Beaugrand et al. 2003; Kirby et al. 2007; Perry et al. 2005; Pörtner and Knust 2007; Wiltshire and Manly 2004). We here suggest that in northern temperate coastal waters, alien species may spearhead biotic responses to climatic warming and that on top of an increasing tide of invaders their share in the recipient biota will be further enhanced by climate change. The barnacle Austrominius modestus originating from the SW Pacific may exemplify this trend and be added to three other alien invaders which also took benefit from recent warming at the shores of the island of Sylt.

At the sheltered upper shore, the cord grass Spartina anglica, introduced into the Wadden Sea already in the $1920 \mathrm{~s}$, recently began to spread again, suggested to be triggered by an earlier warming in spring (Loebl et al. 2006). When Pacific oysters Crassostrea gigas were introduced for farming in the $1980 \mathrm{~s}$, it was assumed that they could not recruit at 


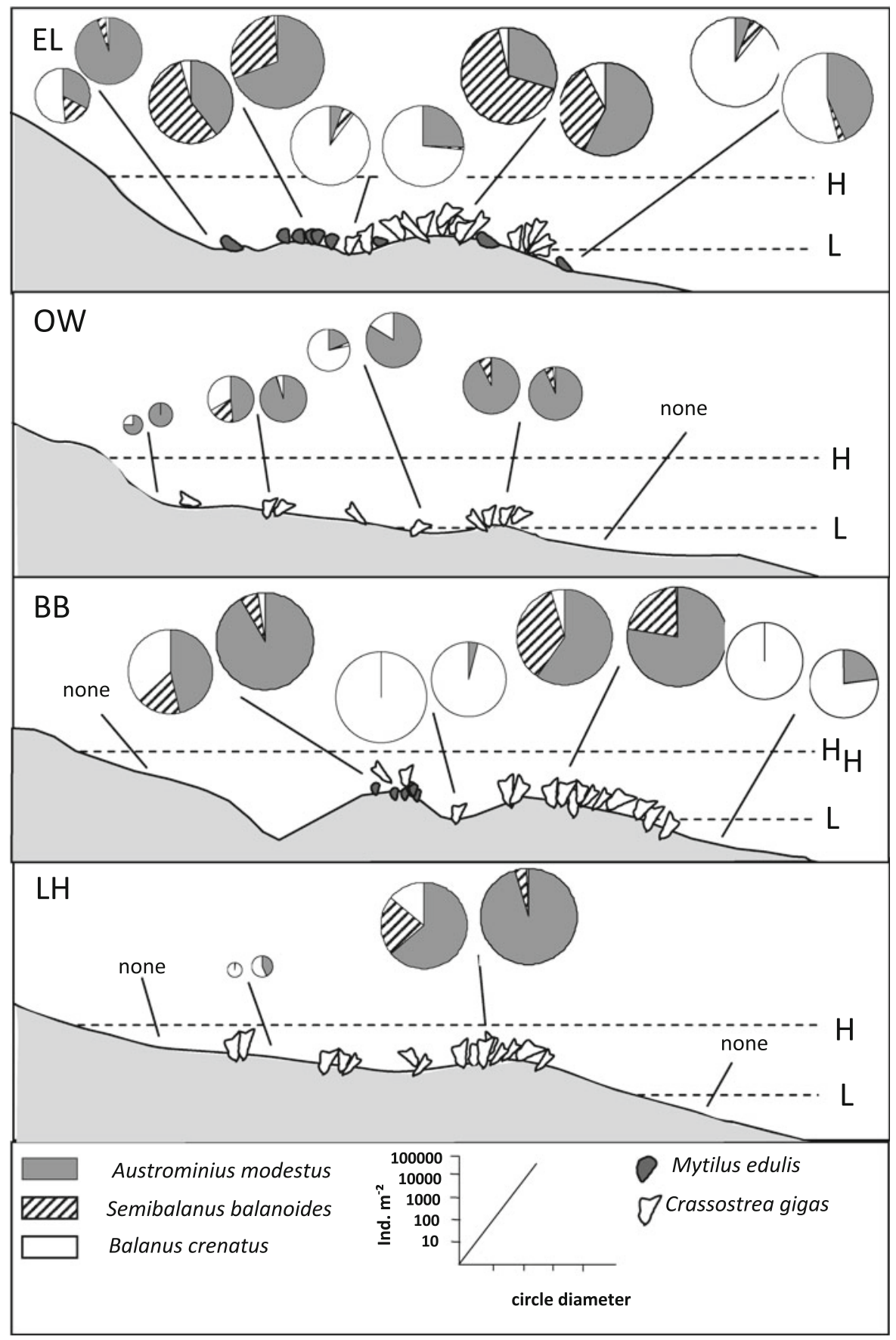

Fig. 3 Transects sampled for barnacles at four sites (see Fig. 1) between mean high $(H)$ and low $(L)$ tide line and in shallow sub tidal, with elevation and habitat schematically indicated. Two circles (May left and September right) for each

the prevailing low temperatures but recent warming in the summer months greatly facilitated their recruitment (Diederich et al. 2005). C. gigas has station indicate total barnacle abundance (individuals $>2 \mathrm{~mm}$ in diameter) by size with relative shares of species given as sectors. Circle diameter-abundance relationship is at the bottom of the diagram

advanced to become the dominant reef builder in the lower tidal zone since the early $2000 \mathrm{~s}$ (Nehls et al. 2006). Another introduced suspension feeder, the 


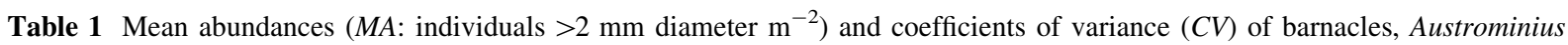
modestus, Semibalanus balanoides and Balanus crenatus, averaged over all transect abundance data in early and late summer 2007

\begin{tabular}{|c|c|c|c|c|c|c|}
\hline & \multicolumn{3}{|l|}{ May } & \multicolumn{3}{|l|}{ September } \\
\hline & A. modestus & S. balanoides & B. crenatus & A. modestus & S. balanoides & B. crenatus \\
\hline MA & 3,756 & 3,859 & 3,625 & 12,474 & 2,728 & 1,589 \\
\hline $\mathrm{CV}$ & 1,718 & 2,151 & 1,934 & 1,639 & 2,020 & 1,838 \\
\hline
\end{tabular}

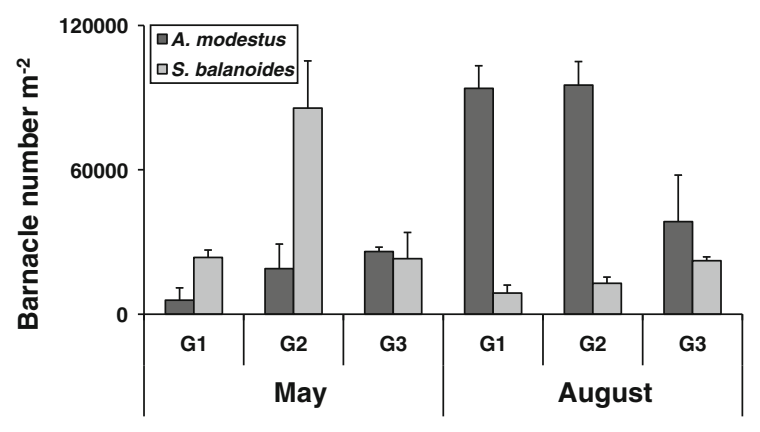

Fig. 4 Abundance (individuals $>2 \mathrm{~mm}$ diameter $\mathrm{m}^{-2}$ ) and standard deviation of Austrominius modestus and Semibalanus balanoides on wooden groins in the intertidal zone at an exposed beach (G1), sand flat (G2) and muddy sand flat (G3) at the island of Sylt (see Fig. 1) in May and September 2007

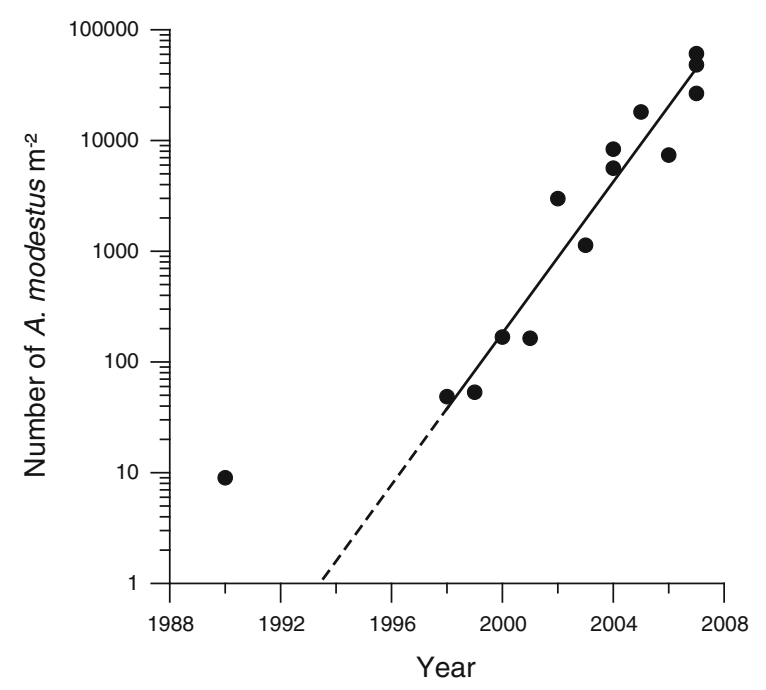

Fig. 5 Mean densities of Austrominius modestus on mussel and oyster beds in the List tidal basin from 1990 to 2007

American slipper limpet Crepidula fornicata, present around Sylt since the $1930 \mathrm{~s}$, has been limited by the occasional severe winters (Thieltges et al. 2004). These severe winters have become rare and the limpet population became as abundant as never before on shallow subtidal bottoms (Thieltges et al. 2009). With A. modestus we may now have a fourth alien species likely to have taken benefit from the recent trend in warming long after its initial introduction because Harms and Anger (1989) already showed that A. modestus is strongly negatively affected by severe winters in the area.

Since the first record in 1955, A. modestus has never been abundant and the two native barnacles $S$. balanoides and B. crenatus dominated in the intertidal and subtidal zones, respectively (Luther 1987, Buschbaum 2002a). After the severe winter 1995/96, local records suggest an exponential increase in population density. With our survey in 2007, it appears that we have just hit the year when A. modestus has become numerically dominant over the others in the intertidal zone. Revisiting some intertidal sites early in 2009 revealed an almost complete takeover of A. modestus on mussels and oysters with almost no $S$. balanoides left anymore (Reise, in prep.).

We analyzed the temperature data recorded at a nearby weather station. No continuous water temperature data are available from 1955 onward, but an analysis of recent data shows that monthly mean water and air temperature are virtually similar. We calculated mean summer temperatures (AprilAugust) and mean winter temperatures (JanuaryMarch). The summer temperatures (Fig. 7a) increase significantly with a rate of about $0.03^{\circ} \mathrm{C}$ year ${ }^{-1}$ $(P<0.0001)$. A plot of mean winter temperatures versus mean summer temperatures shows that since the last strong winter in 1995/1996 winter temperatures were always above $0.5^{\circ} \mathrm{C}$ and summer temperatures were always above $13^{\circ} \mathrm{C}$ (Fig. 7b). In fact, 6 out of 10 warmest summers and 5 out of 10 warmest winters occurred during the past decade (1999-2008).

Increased temperatures during summer months may enhance the breeding success in A. modestus which is a cross-fertilising hermaphrodite with multiple broods 

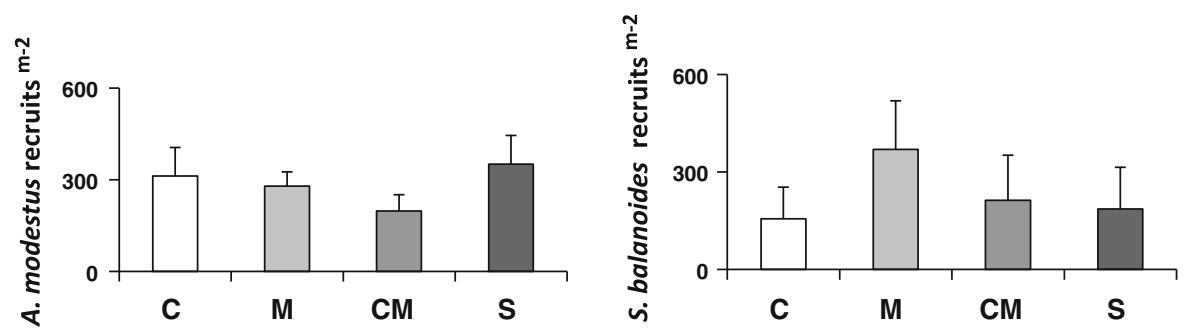

Fig. 6 Settled individuals (basal diameter $>2 \mathrm{~mm}$ ) per panel of Austrominius modestus (left) and Semibalanus balanoides (right) inside experimental rings of oysters $(C)$, mussels $(M)$, both mixed $(C M)$ and bare sediment $(S)$ in August 2007
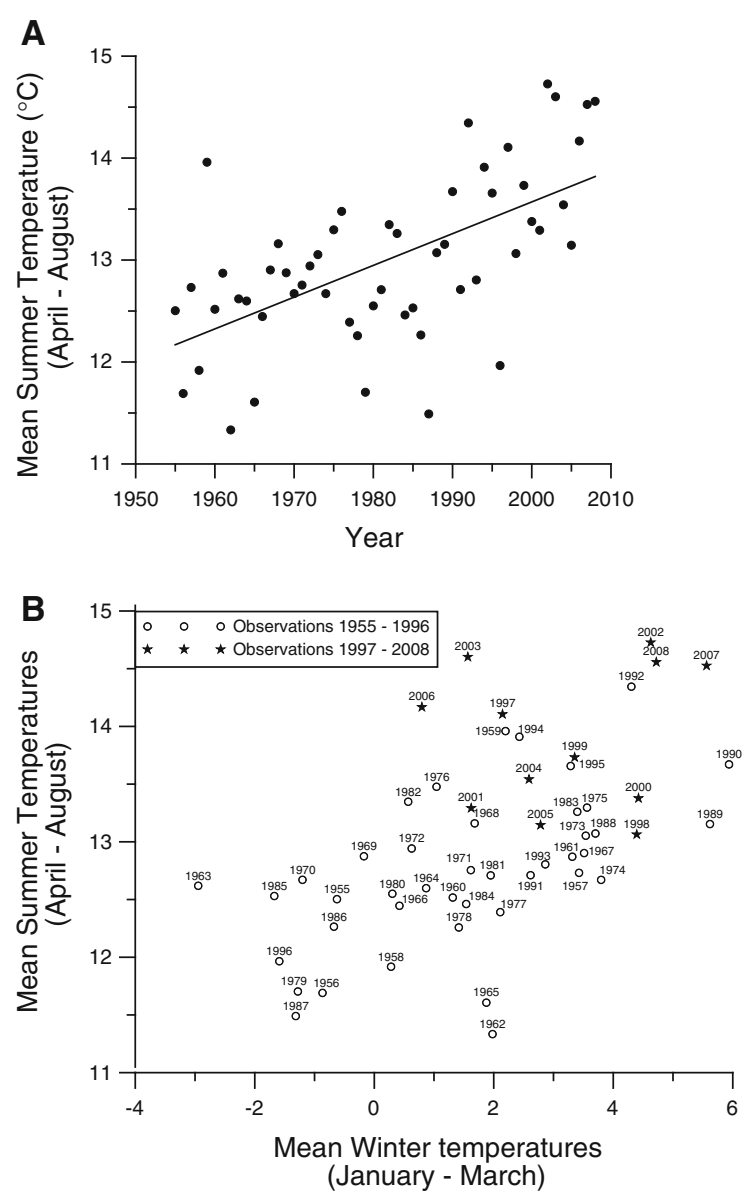

Fig. 7 a Mean summer air temperature in ${ }^{\circ} \mathrm{C}$ (April-August) since 1955 at the weather station List on Sylt. Best linear fit is significant $\left(N=54 ; P<0.0001 ; R^{2}=0.358\right)$ and indicates a linear temperature increase of $0.03^{\circ} \mathrm{C}$ year ${ }^{-1}$. Data were kindly provided by Deutscher Wetterdienst. b A plot of mean summer air temperature in ${ }^{\circ} \mathrm{C}$ (April-August) versus mean winter temperature (January-March) since 1955 at the weather station List on Sylt. Data were kindly provided by Deutscher Wetterdienst throughout the warmer season, particularly with water temperatures above $20^{\circ} \mathrm{C}$ (Harms 1999, O'Riordan and Muphy 2000). Substantial settlement of juveniles takes place from June to October, and newly metamorphosed A. modestus grow rapidly and can reach maturity in about 8 weeks, while longevity is $<2$ years (Harms and Anger 1983). By contrast, the native S. balanoides is a boreal cold water species, with peak settlement already between April and May. It grows slowly and may get several years old. B. crenatus is also a boreal cold water species with settlement of larvae mainly from April to May (Luther 1987). This may explain the reverse dynamics of barnacle abundances observed in the course of our survey in summer 2007. Abundance of $A$. modestus increased, while numbers of $S$. balanoides and B. crenatus decreased.

Abundances of A. modestus and S. balanoides were highest in the low intertidal zone where mixed mussel and oyster beds occurred whereas $B$. crenatus was more abundant in the subtidal zone. A. modestus and $S$. balanoides are both capable of oxygen uptake from air and are tolerant to moderate desiccation stress, whereas the subtidal B. crenatus is not able to survive long periods of emergence (Foster 1971). In contrast to $S$. balanoides, $A$. modestus has the ability to settle in the upper subtidal as well (Harms and Anger 1983, Watson et al. 2005). Of the three barnacle species, A. modestus has the widest vertical range in the littoral zone, and this is reflected by the lowest coefficient of variation over all transect abundance data in this study. On wooden groins, A. modestus occurred higher up than $S$. balanoides. This agrees with observations at other shores (Foster 1971; Lawson et al. 2004). Further, we found no evidence of substrate specifity nor for a preferred surrounding by either oysters or mussels, and settlement occurred 
at the sheltered as well as the exposed shore. A. modestus seems to have a wider habitat niche than the native barnacles at Sylt. Overall, A. modestus is bound to warmer waters and there behaves more opportunistically than $S$. balanoides and B. crenatus (for review see Rainbow 1984). We know of no other environmental trend (i.e., no declining salinity, van Beusekom et al. 2008; no increasing food supply, van Beusekom et al. 2009) nor space for settlement) than temperature which could explain the observed boom in abundance of A. modestus in 2007. Differences in total density of all barnacle species at the study sites are typical for the area and may be caused by variable recruitment success and predation pressure.

We observed A. modestus frequently settling upon S. balanoides. Nevertheless, we do not assume effective competition for space as it has been suggested for coasts in southern Britain (Crisp 1958) because there is usually sufficient empty space still available on groins as well as on dead shells and living epibenthic molluscs at the sedimentary shores around Sylt. Barnacle diversity at the shore of Sylt is low compared to more southern locations as for example Lough Hyne on the south coast of Ireland. There three more species, Chthamalus montagui, C. stellatus and Verruca stroemia, are common (Lawson et al. 2004; Watson et al. 2005). Inside this Lough, A. modestus was still absent in the 1950s, was recorded at low numbers in the $1980 \mathrm{~s}$, and finally attained dominance in the summer of 2001. Thus, even with five other species being abundant, no evidence for diversity resistance was found, nor for displacement of natives, and total barnacle cover has increased over the decades.

At Sylt we lack quantitative data on barnacles from earlier times but a very strong variability in cirripede larvae and settlement has been noted (Buschbaum 2002b). This, together with extreme patchiness of biogenic substrate for settlement, may preclude competitive displacement at the scale of a shore. S. balanoides is more likely to decline in range and abundance for climatic reasons (Wethey and Woodin 2008). With the alien A. modestus there is a potent substitute to fill the gap in case $S$. balanoides fades away because of warming.

However, it cannot be excluded that $A$. modestus may pre-empt space before Chthamalus spp.- - now common at more southern shores of the North Seacould expand their range into the eastern North Sea in the wake of climatic warming. Barnacles are easily shipped around the world or are transported with farmed oysters (Bishop 1951; Kerckhof and Cattrijsse 2001; Wolff and Reise 2002), and several alien barnacles seem to be ante portas to become established once the currently too cold waters warm up further in the North Sea (Kerckhof and Cattrijsse 2001; Kerckhof et al. 2007; Wiegemann 2008). The availability of artificial substrates, floating or fixed, may ease their immigration. Thus, there are good prospects that the low-diversity balanid fauna in the eastern North Sea will become invaded by more barnacles in addition to A. modestus.

Regardless whether aliens will have negative or positive effects on native barnacles or other biota in the recipient ecosystem, the addition contributes to the irreversible transformation of the inherited and co-evolved coastal biota into a more fortuitous and globalized assemblage where anything goes. Presumably this emerging assemblage will be better prepared for the changes to come than a pristine biota. However, the prize is a loss in regional identity and integrity.

Acknowledgments We thank Elisabeth Herre for substantial help with the figures. Patrick Polte, Nils Volkenborn, Alfred Resch and Kay von Böhlen were essential to set-up the ringexperiment. Heike Büttger and Georg Nehls provided longterm data on barnacle abundance attached to beds of mussels and oysters.

\section{References}

Albrecht A, Reise K (1994) Effect of Fucus vesiculosus covering intertidal mussel beds in the Wadden Sea. Helgol Meeresunters 48:243-256

Alpert P (2006) The advantages and disadvantages of being introduced. Biol Invasions 8:1523-1534

Armonies W, Herre E, Sturm M (2001) Effects of the severe winter 1995/96 on the benthic macro fauna of the Wadden Sea and the coastal North Sea near the island of Sylt. Helgol Mar Res 55:170-175

Barnes H, Barnes M (1968) Elminius modestus Darwin: a recent extension of the distribution and its present status on the southern part of the French Atlantic coast. Cahiers des Biologie Marine 9:261-268

Barney JN, Whitlow TH (2008) A unifying framework for biological invasions: the state factor model. Biol Invasions 10:259-272

Beare DJ, Burns F, Greig A, Jones EG, Peach K, Kienzle M, McKenzie E, Reid DG (2004) Long-term increases in prevalence of North Sea fishes having southern biogeographic affinities. Mar Ecol Prog Ser 284:269-278 
Beaugrand G, Brander KM, Lindley JA, Souissi S, Reid PC (2003) Plankton effect on cod recruitment in the North Sea. Nature 426:661-664

Bishop MWH (1947) Establishment of an immigrant barnacle in British coastal waters. Nature 159:501

Bishop MWH (1951) Distribution of barnacles by ships. Nature 167:531

Buckeridge JS, Newman WA (2010) A review of the subfamily Elminiinae (Cirripedia: Thoracica: Austrobalanidae), including a new genus, Protelminius nov., from the Oligocene of New Zealand. Zootaxa 2349:39-54

Buschbaum C (2002a) Predation on barnacles of intertidal and sub tidal mussel beds in the Wadden Sea. Helgol Mar Res $56: 37-43$

Buschbaum C (2002b) Recruitment patterns and biotic interactions of barnacles (Cirripedia) on mussel beds (Mytilus edulis L.) in the Wadden Sea. Berichte zur Polar- und Meeresforschung 408:143

Büttger H, Asmus H, Asmus R, Buschbaum C, Dittmann S, Nehls G (2008) Community dynamics of intertidal softbottom mussel beds over two decades. Helgol Mar Res 62:23-36

Carlton JT (1985) Transoceanic and interoceanic dispersal of coastal marine organisms: the biology of ballast water. Oceanogr Mar Biol Ann Rev 23:313-374

Crisp DJ (1958) The spread of Elminius modestus Darwin in North-West-Europe. J Mar Biol Ass UK 37:483-520

Crisp DJ (1964) The effects of the winter of 1962/63 on the British marine fauna. Helgol wiss Meeresunters 10:313-327

Crooks JA (2005) Lag times and exotic species: the ecology and management of biological invasions in slow-motion. Ecoscience 12(3):316-329

Crooks JA, Soulé ME (1999) Lag times in population explosions of invasive species: causes and implications. In: Sandlund OT, Schei PJ, Viken A (eds) Invasive species and biodiversity management. Kluwer Academic Press, Dordrecht, pp 103-125

Darwin C (1854) A monograph on the subclass Cirripedia, with figures of all species. The Balanidae (or sessile cirripedes), the Verrucidae, etc. Ray Society, London, p 684

Diederich S, Nehls G, van Beusekom JEE, Reise K (2005) Introduced Pacific oysters (Crassostrea gigas) in the northern Wadden Sea: invasion accelerated by warm summers? Helgol Mar Res 59:97-106

Dukes JS, Mooney HA (1999) Does global change increase the success of biological invaders? Trends Ecol Evol 14:135139

Foster BA (1971) Desiccation as a factor in the intertidal zonation of barnacles. Mar Biol 8:12-29

Franke H-D, Gutow L (2004) Long-term changes in the macrozoobenthos around the rocky island of Helgoland (German Bight, North Sea). Helgol Mar Res 58:303-310

Galil BS (2009) Taking stock: inventory of alien species in the Mediterranean sea. Biol Invasions 11:359-372

Gätje C, Reise K (1998) Ökosystem Wattenmeer, Austausch-, Transport- und Stoffumwandlungsprozesse. Springer, Berlin, p 570

Görlitz S (2005) Neue Riffe im Wattenmeer: Die Pazifische Auster Crassostrea gigas und ihre assoziierte Lebensgemeinschaft. Diploma thesis, University of Kiel, pp 66
Grosholz E (2002) Ecological and evolutionary consequences of coastal invasions. Trends Ecol Evol 17:22-27

Harms J (1999) The neozoan Elminius modestus Darwin (Crustacea, Cirripedia): possible explanations for its successful invasion in European water. Helgol Meeresunters 52:337-345

Harms J, Anger K (1983) Seasonal, annual, and spatial variation in the development of hard bottom communities. Helgol Meeresunters 36:137-150

Harms J, Anger K (1989) Settlement of the barnacle Elminius modestus on test panels at Helgoland (North Sea): a ten year study. Topics in marine biology. Sci Mar 53:417-421 Ed by JD Ros

Kerckhof F, Cattrijsse A (2001) Exotic Cirripedia (Balanomorpha) from buoys off the Belgian coast. Senckenb Marit 31:245-254

Kerckhof F, Haelters J, Gollasch S (2007) Alien species in the marine and brackish ecosystem: the situation in Belgian waters. Aquat Invasions 2:243-257

Kirby RR, Beaugrand G, Lindley JA, Richrdson AJ, Edwards M, Reid PC (2007) Climate effects and benthic-pelagic coupling in the North Sea. Mar Ecol Prog Ser 330:31-38

Kochmann J, Buschbaum C, Volkenborn N, Reise K (2008) Shift from native to alien oysters: differential effects of ecosystem engineers. J Exp Mar Biol Ecol 364:1-10

Kühl H (1954) Über das Auftreten von Elminius modestus Darwin in der Elbmündung. Helgol wiss Meeresunters 5:53-56

Kühl H (1963) Die Verbreitung von Elminius modestus Darwin (Cirripedia, Thoracica) an der Deutschen Küste. Crustaceana 5:99-111

Lawson J, Davenport J, Whitaker A (2004) Barnacle distribution in Lough Hyne Marine nature reserve: a new baseline and an account of invasion by the introduced Australasian species Elminius modestus Darwin. Est Coast Shelf Sci 60:729-735

Loebl M, van Beusekom JEE, Reise K (2006) Is spread of the neophyte Spartina anglica recently enhanced by increasing temperatures? Aquat Ecol 40:315-324

Luther G (1977) Bewuchsuntersuchungen auf Natursteinsubstraten im Gezeitenbereich des Nordsylter Wattenmeeres: sessile und hemisessile Tiere. Helgol wiss Meeresunters 29:375-403

Luther G (1987) Seepocken der deutschen Küstengewässer. Helgol Meeresunters 41:1-43

MacKenzie BR, Schiedek D (2007) Daily ocean monitoring since the $1860 \mathrm{~s}$ shows record warming of northern European seas. Global Change Biology 13:1335-1347

Martens P, van Beusekom JEE (2008) Zooplankton response to a warmer northern Wadden Sea. Helgol Mar Res 62:6775

Mieszkowska N, Kendall MA, Hawkins SJ, Leaper R, Williamson P, Hardman-Mountford NJ, Southward AJ (2006) Changes in the range of some common rocky shore species in Britain-a response to climate change? Hydrobiologia 555:241-251

Nehls G, Büttger H (2006) Miesmuschelmonitoring 1998-2005 im Nationalpark Schleswig-Holsteinisches Wattenmeer. Landesamt für den Nationalpark, Schleswig-Holsteinisches Wattenmeer, p 165 
Nehls G, Diedrich S, Thieltges D, Strasser M (2006) Wadden sea mussel beds invaded by oyster and slipper limpets: competition or climate control? Helgol Mar Res 60:135143

O'Riordan RM, Muphy O (2000) Variation in the reproductive cycle of Elminius modestus in southern Ireland. J Mar Biol Ass UK 80:607-616

O'Riordan RM, Culloty S, Davenport J, McAllen R (2009) Increases in the abundance of the invasive barnacle Austrominius modestus on the Isle of Cumbrae, Scotland. Mar Biodivers Rec 2:1-4

Occhipinti-Ambrogi A (2007) Global change and marine communities: alien species and climate change. Mar Pollut Bull 55:342-352

Parmesan C, Yohe G (2003) A globally coherent fingerprint of climate change impacts across natural systems. Nature 421:37-42

Perry AL, Low PJ, Ellis JR, Reynolds JD (2005) Climate change and distribution shifts in marine fishes. Science 308:1912-1915

Pörtner HO, Knust R (2007) Climate change affects marine fishes through the oxygen limitation of thermal tolerance. Science 315:95-97

Rainbow PS (1984) An introduction to the biology of British littoral barnacles. Field Stud 6:1-51

Reichert K, Buchholz F (2006) Changes in the macrozoobenthos of the intertidal zone at Helgoland (German Bight, North Sea): a survey of 1984 repeated in 2002. Helgol Mar Res 60:213-223

Reise K (1998) Pacific oysters invade mussel beds in the European Wadden Sea. Senckenb Marit 28:167-175

Reise K, van Beusekom JEE (2008) Interactive effects of global and regional change on a coastal ecosystem. Helgol Mar Res 62:85-91

Reise K, Olenin S, Thieltges DW (2006) Are aliens threatening European aquatic coastal ecosystems? Helgol Mar Res 60:77-83

Sax DF, Stachowicz JJ, Brown JH et al (2007) Ecological and evolutionary insights from species invasions. Trends Ecol Evol 22:465-471

Southward AJ, Hawkins SJ, Burrows MT (2005) Seventy years' observations of changes in distribution and abundance of zooplankton and intertidal organisms in the western English Channel in relation to rising sea temperature. J Therm Biol 20:127-155
Thieltges DW, Strasser M, van Beusekom JEE, Reise K (2004) Too cold to prosper-winter mortality prevents population increase of the introduced American slipper limpet Crepidula fornicata in northern Europe. J Exp Mar Biol Ecol 311:375-391

Thieltges DW, Prinz K, Reise K, Jensen KT (2009) Invaders interfere with native parasite-host interactions. Biol Invasions. doi:10.1007/s10530-008-9350-y

Underwood AJ (1997) Experiments in ecology. Cambridge University Press, Cambridge, p 504

van Beusekom JEE, Weigelt-Krenz S, Martens P (2008) Longterm variability of winter nitrate concentrations in the Northern Wadden Sea driven by freshwater discharge, decreasing riverine loads and denitrification. Helgol Mar Res 62:49-57

van Beusekom JEE, Loebl M, Martens P (2009) Distant riverine nutrient supply and local temperature drive the longterm phytoplankton development in a temperate coastal basin. J Sea Res 61:26-33

Walther GR, Post E, Convey P, Menzel A, Parmesan C, Beebee TJC, Fromentin JM, Hoegh-Guldberg O, Bairlein F (2002) Ecological responses to recent climate change. Nature 416:389-395

Watson DI, O'Riordan RM, Barnes DKA, Cross T (2005) Temporal and spatial variability in the recruitment of barnacles and the local dominance of Elminius modestus Darwin in SW Ireland. Est Coast Shelf Sci 63:119-131

Westphal MI, Browne M, MacKinnon K, Noble I (2008) The link between international trade and the global distribution of invasive species. Biol Invasions 10:391-398

Wethey DS, Woodin SA (2008) Ecological hind casting of biogeographic responses to climate change in the European intertidal zone. Hydrobiologia 606:139-151

Wiegemann M (2008) Wild cyprids metamorphosing in vitro reveal the presence of Balanus amphitrite Darwin, 1854 in the German Bight basin. Aquat Invasions 3:235-238

Wiltshire KH, Manly BFJ (2004) The warming trend at Helgoland roads, North Sea: phytoplankton responses. Helgol Mar Res 58:269-273

Wolff WJ, Reise K (2002) Oyster imports as a vector for the introduction of alien species into northern and western European coastal waters. In: Leppäkoski E et al (eds) Invasive aquatic species of Europe. Kluwer Acad Press, Netherlands, pp 193-205 